\title{
Analisis Kepuasan Pelanggan (Penumpang Domestik) Terhadap Kualitas Pelayanan Di Terminal Penumpang Pelabuhan Sri Bintan Pura Tanjungpinang
}

\author{
Roma Dormawaty ${ }^{1}$, Pande Sijabat ${ }^{2}$, Muhammad Dimas Setiawan ${ }^{3}$ \\ 1,2, 3 Prodi Ketatalaksanaan Angkutan Laut dan Kepelabuhanan \\ Sekolah Tinggi Ilmu Pelayaran, Jakarta \\ Jl. Marunda Makmur No. 1 Cilincing, Jakarta Utara. Jakarta 14150
}

\begin{abstract}
Abstrak
Pelabuhan Sri Bintan Pura merupakan salah satu pelabuhan yang melayani segala kegiatan yang berhubungan dengan kebutuhan orang yang akan berpergian menggunakan jasa angkutan laut. Penumpang Domestik Pelabuhan Sri Bintan Pura masih merasa kurang puas terhadap pelayanan yang diberikan, seperti lahan parkir yang belum ditata secara bener, antrian panjang masuk dan atau keluar pelabuhan, ruang tunggu terminal penumpang yang masih dalam perbaikan serta fasilitas bagi penyadang disfable yang belum memadai. Masalah yang diteliti adalah bagaimana tingkat kepuasan penumpang (domestik) terhadap pelayanan di terminal penumpang pelabuhan Sri Bintan Pura Tanjungpinang. Kemudian tujuan dilaksanakannya penelitian ini yaitu untuk mengetahui dan menganalisis tingkat kepuasan penumpang terhadap pelayanan di pelabuhan Sri Bintan Pura Tanjungpinang. Metode penelitian yang digunakan adalah kuantitatif dengan teknik analisa data menggunakan Indenx Performance Analysis (IPA) dan Customer Satisfaction Index (CSI). Dari hasil penelitian diperoleh tingkat kepuasan pelanggan berdasarkan Customer Satisfaction Index atas pelayanan yang ada di pelabuhan Sri Bintan Pura Tanjungpinang, diperoleh penumpang domestik di pelabuhan Sri Bintan Pura cukup puas namun belum maksimal atas pelayanan yang di berikan oleh penyelenggara pelabuhan Sri Bintan Pura Tanjungpinang. Hal ini dapat dilihat dari perhitungan hasil diatas rata-rata masih mengkha-watirkan.
\end{abstract}

Copyright (C) 2020, Prosiding Seminar Pelayaran dan Riset Terapan

Kata Kunci: analisis, kepuasan pelanggan, pelabuhan

Permalink/ DOI : https://doi.org/10.36101/pcsa.v2i1.125

\section{PENDAHULAN}

Dalam era globalisasi ini, kebutuhan akan adanya transportasi sangatlah penting dirasakan oleh semua pihak, baik kalangan atas, mengengah, ataupun bawah. Sarana transportasi dapat berupa darat, laut, dan udara. Sebagai negara kepualauan, salah satu transportasi yang sangat berperan penting di Indonesia yaitu transportasi laut, tidak hanya sebagai alat penghubung dari satu wilayah ke wilayah lain lebih dari itu sebagai alat angkut perdagangan nasional maupun internasional. Salah satu hal yang penting dalam transportasi laut ialah pelabuhan.

Pelabuhan yang merupakan sebuah fasilitas di ujung samudera, sungai, atau danau untuk menerima kapal dan memindahkan barang maupun penumpang kedalamnya, juga sebagai pintu gerbang dan penghubung kepentingan antar daerah, pulau dan bangsa yang dapat memajukan daerah belakangnya. Selain itu, pelabuhan merupakan salah satu terminal transportasi yang berperan penting dalam pertumbuhan ekonomi suatu kawasan dan secara global akan mempengaruhi kesejahteraan suatu bangsa, terutama di Indonesia sebagai negara maritim. Salah satu fungsi pelabuhan ditinjau dari segi penggunaannya adalah sebagai embarkasi dan debarkasi penumpang (Undang-Undang No 17 Tahun 2008 Tentang Pelayaran). Dalam fungsinya tersebut, berarti pelabuhan harus melayani segala bentuk kegiatan dan kepentingan yang berhubungan dengan kebutuhan orang yang akan bepergian dengan menggunakan sarana jasa angkatan laut. Oleh karena itu, pelayanan yang diberikan kepada penumpang harus dikalsanakan secara optimal dan berkualitas.

Pelayanan yang optimal dan berkualitas tentunya tidak terlepas dari hubungan penyedia pelayanan jasa dengan pelanggan. Dalam hal ini, yang dimaksud dari penyedia pelayanan jasa adalah segala bentuk fasilitas dan pelaksana 
fasilitas tersebut dalam menjalankan kepentingan yang saling berkaitan untuk melayani pelanggan, sedangkan pelanggan adalah "orang yang membeli atau menggunakan produknya dan merupakan orang yang berinteraksi dengan organisasi setelah proses menghasilkan produk/jasa" (Fandy Tjiptono, 2002:128). Berkaitan dengan hal tersebut, dua aspek yang harus diperhatikan oleh penyelenggara pelabuhan sebagai public service adalah fasilitas dan pelaksana fasilitas sesuai dengan kinerja dari penyedia pelayanan jasa dan kepentingan pengguna jasa yang diukur berdasarkan kepuasan dari pengguna jasa atau penumpang pelabuhan. Penyedia pelayanan jasa dalam melaksanakan tugasnya harus mengetahui hal - hal apa saja yang dianggap penting oleh penumpang atau pengguna jasa, dan kemudian harus berusaha untuk menghasilkan kinerja yang seoptimal mungkin sehingga dapat memberikan kepuasan bagi pelanggan.

Menurut (Kotler \& Keller, 2007) kepuasaan adalah perasaan senang atau kecewa seseorang yang muncul setelah membandingkan antara persepsi atau kesannya kinerja atau hasil dari suatu produk dan harapan - harapannya. Dimana penumpang akan merasa puas jika pelayanan yang dirasakan dapat memenuhi dan melebihi harapan dari penumpang sebaliknya penumpang akan merasa kurang puas jika pelayanan yang di rasakan tidak dapat memenuhi harapan dari penumpang tersebut.

Namun pada kenyatanya, pada saat peneliti melaksanakan penelitian di pelabuhan Sri Bintan Pura Tanjungpinang, penyelenggara pelabuhan disana sebagai public service masih belum maksimal dalam pemberian pelayanan kepada penumpang. Sehingga penumpang merasa kurang puas akan pelayanan yang telah diberikan.

Pelabuhan Sri Bintan Pura salah satu pelabuhan yang melayani segala kegiatan yang berhubungan dengan kebutuhan orang yang akan berpergian menggunakan jasa angkutan laut. Pelabuhan sri bintan pura termasuk dalam pelabuhan Laut Tanjungpinang yang merupakan pelabuhan kelas II berdasarkan Peraturan Menteri Perhubungan No. 36 Tahun 2012 Tentang Organisasi dan Tata Kerja Kantor Kesyahbandaran dan Otoritas Pelabuhan, yang dikelola secara komersial oleh PT Pelindo I (persero) Cabang Tanjungpinang.

Pelabuhan Sri Bintan Pura merupakan salah satu objek vital di Kota Tanjungpinang yang menjadi pintu gerbang utama bagi masuknya wisatawan lokal dan mancanegara untuk menuju ke kota Tanjungpinang. Sehingga berpotensi besar untuk menjadi salah satu penyumbang income daearah Tanjungpinang. Pelabuhan ini menghubungkan kota Tanjungpinang dengan pelabuhan-pelabuhan di sebelah utara (pelabuhan Lobam dan pelabuhan Bulang Linggi), dengan kepulauan di sebelah barat, seperti pelabuhan Tanjung Balai (pulau Karimun), pelabuhan Telaga Punggur di pulau Batam, Kepulauan di sebelah selatan seperti pulau Lingga dan Singkep, Natuna dan seluruh Pelabuhan di Kepulauan Riau pada umumnya. Untuk pelayaran ke luar negeri, pelabuhan Sri Bintan Pura juga mempunyai jalur perhubungan ke Singapura (Harbour Front dan Tanah Merah) serta Malaysia (Stulang Laut).

Terminal penumpang pada pelabuhan Sri Bintan Pura terbagi menjadi dua terminal penumpang antara lain terminal penumpang domestik dan terminal penumpang internasional. Dimana terminal penumpang domestik melayani arus naik turun penumpang antar pulau - pulau di Indonesia, sedangkan terminal penumpang internasional melayani arus naik turun penumpang ke negara tetangga yang berdekatan dengan kota Tanjungpinang seperti singapura dan Malaysia.

Terminal penumpang domestik di pelabuhan Sri Bintan Pura sangat berperan penting dalam kehidupan masyarakat kota Tanjungpinang, dimana terminal penumpang domestik melayani jasa naik turun penumpang dari ke pulau - pulau terdekat dari kota Tanjungpinang. Kebanyakan dari mereka memliki tujuan untuk keperluan wisata, bisnis/perdagangan, dan pemenuhan kebutuhan (pekerjaan, pendidikan, dan sandang pangan).

Seiring berkembangnya jaman dan kebutuhan masyarakat terhadap pentingnya transportasi laut untuk melakukan perpindahan barang maupun penumpang dari tempat satu ke tempat lain secara efektif dan efesien, oleh karena itu tuntutan penyelenggara pelabuhan untuk menyediakan pelayanan jasa yang berkualitas serta harus mengetahui hal - hal apa saja yang di anggap penting bagi pengguna jasa sangat ditekankan, sehingga dapat memenuhi kepuasan pengguna jasa secara optimal.

Berdasarkan observasi yang dilakukan peneliti selama penelitian, ditemukan bahwa penumpang domestik pelabuhan sri bintan pura masih merasa kurang puas terhadap pelayanan yang diberikan, seperti lahan parkir yang belum ditata secara bener, antrian panjang masuk dan atau keluar pelabuhan, ruang tunggu terminal penumpang yang masih dalam perbaikan serta fasilitas bagi penyadang disfable yang belum memadai.

Atas dasar uraian di atas dan mengingat pentingnya hal - hal tersebut, maka peneliti tertarik untuk mengetahui bagaimana kualitas pelayanan yang diberikan di pelabuhan sri bintan pura, hal ini dilakukan untuk mengetahui keinginan serta 
harapan penumpang agar pelayanan yang ada dapat memberikan kepuasan penumpang.

Berdasarkan hal tersebut peneliti menguraikan identifikasi masalah, yaitu:

1. Kurangnya kualitas pelayanan yang ada di pelabuhan sri binta pura Tanjungpinang.

2. Fasilitas pelabuhan yang masih belum memadai.

3. Tingkat kepuasan penumpang domestik terhadap pelayanan jasa di pelabuhan Sri Bintan Pura Tanjungpinang yang belum maksimal.

Berdasarkan uraian yang telah disampaikan dalam latar belakang, peneliti merumuskan permasalahan yaitu bagaimana tingkat kepuasan penumpang (domestik) terhadap pelayanan di terminal penumpang pelabuhan Sri Bintan Pura Tanjungpinang?

Kemudian tujuan dilaksanakannya penelitian ini yaitu untuk mengetahui dan menganalisis tingkat kepuasan penumpang terhadap pelayanan di pelabuhan Sri Bintan Pura Tanjungpinang.

\section{METODE}

Metode Pendekatan yang digunakan dalam penelitian ini adalah metode pendekatan kuantitatif. Peneliti mengambil tempat penelitian Kantor Kesyahbandaran dan Otoritas Pelabuhan Kelas II Tanjungpinang.

Pada penelitian ini teknik yang digunakan dalam pengambilan sampel adalah menggunakan metode sampel kebetulan (accidental sampling), teknik penentuan sampel berdasarkan kebetulan, yaitu siapa saja yang secara kebetulan/incidental bertemu dengan peneliti dapat digunakan sebagai sampel, bila dipandang orang yang kebetulan ditemui itu cocok sebagai sumber data (Sugiyono, 2013:122). Menurut Arikunto (2010:134 - 185) apabila populasi penelitian berjumlah kurang dari 100 maka sampel yang diambil adalah semuanya, namun apabila populasi penelitian berjumlah lebih dari 100 maka sampel yang dapat diambil antara $10-15 \%$ atau $20-25 \%$ atau lebih. Dari teori arikunto yang dijadikan pedoman peneliti maka peneliti mengambil jumlah sampel sebanyak 50 penumpang domestik di terminal pelabuhan pada bulan September 2017.

Dalam penelitian ini peneliti menggunakan teknik analisis data untuk mengetahui seberapa besarkah tingkat kepuasan penumpang domestik terhadap kualitas pelayanan dengan mengetehaui tingkat kinerja dari penyedia jasa dan tingkat kepentingan dari pengguna jasa serta mengetahui atribut-atribut pelayanan yang menurut penumpang memberikan pengaruh yang besar terhadap kepuasan penumpang, di terminal penumpang pelabuhan Sri Bintan Pura dan Metode yang digunakan harus sesuai dengan bidang kajian penelitian jenis - jenis analisis kuantitatif, sehingga data dapat menjadi lebih sederhana dan mudah dibaca serta mudah diinterpretasikan. Analisis data survey menggunakan data opini responden untuk mengetahui persepsi pengguna jasa terminal penumpang domestik melalui Customer Satisfaction Index (CSI) dan Importance Perfomance Analysis (IPA).

\section{HASIL DAN PEMBAHASAN}

Penelitian ini menggunakan data yang didasarkan pada dimensi kualitas pelayanan yang mengacu pada standar pelayanan penumpang angkutan laut menurut Peraturan Menteri Perhubungan No 119 Tahun 2015. Peraturan Menteri tersebut mengatur tentang Pelayanan keselamatan, pelayanan keamanan dan ketertiban, pelayanan kehandalan atau keteraturan, pelayanan kenyamanan, pelayanan kemudahan, dan pelayanan kesetaraan.

Data tersebut diperoleh dengan menggunakan teknik angket (Quesioner). Teknik angket digunakan untuk mengetahui tingkat kepuasan pengguna jasa dengan melihat tingkat kinerja (X) pelabuhan Sri Bintan Pura dan tingkat kepentingan (Y) penumpang domestik di pelabuhan Sri Bintan Pura dengan pernyataan masing - masing variabel berjumlah 31 butir pernyataan dengan menggunakan sampel 50 responden (penumpang domestik).

Tabel 1.Sebaran Karakteristik Pengguna Jasa

\begin{tabular}{|c|l|c|c|}
\hline Kategori & \multicolumn{1}{|c|}{ Karakteristik } & JML & $\%$ \\
\hline \multirow{4}{*}{$\begin{array}{c}\text { Jenis } \\
\text { Kelamin }\end{array}$} & Laki - laki & 31 & $62 \%$ \\
\cline { 2 - 4 } & Perempuan & 19 & $38 \%$ \\
\hline \multirow{5}{*}{ Pendidikan } & $<$ Setingkat SD & 0 & $0 \%$ \\
\cline { 2 - 4 } & SLTP & 5 & $10 \%$ \\
\cline { 2 - 4 } & SLTA & 24 & $48 \%$ \\
\cline { 2 - 4 } & Sarjana / Lebih & 21 & $42 \%$ \\
\hline \multirow{5}{*}{ Usia } & $<20$ Tahun & 9 & $18 \%$ \\
\cline { 2 - 4 } & $21-30$ Tahun & 23 & $46 \%$ \\
\cline { 2 - 4 } & $31-40$ Tahun & 14 & $28 \%$ \\
\cline { 2 - 4 } & $41-50$ Tahun & 4 & $8 \%$ \\
\cline { 2 - 4 } & $>50$ Tahun & 0 & $0 \%$ \\
\hline \multirow{5}{*}{ Pekerjaan } & PNS/TNI/POLRI & 9 & $18 \%$ \\
\cline { 2 - 4 } & Wiraswasta & 14 & $28 \%$ \\
\cline { 2 - 4 } & Nelayan & 2 & $4 \%$ \\
\cline { 2 - 4 } & Pelajar/Mahasiswa & 19 & $38 \%$ \\
\cline { 2 - 4 } & Lain-lain & 6 & $12 \%$ \\
\hline
\end{tabular}


Melalui tabel 1 menunjukan besarnya prosentase dari yang terbesar sampai terkecil untuk masing - masing karakterik penumpang domestik angkutan laut di pelabuhan Sri Bintan Pura Tanjungpinang pada kategori dimana dapat diketahui bahwa sebagian besar penumpang domestik di pelabuhan Sri Bintan Tanjungpinang berjenis kelamin laki - laki memiliki pendidikan SLTA/sederajat dan berusia 21 sampai 30 tahun yang notabene seorang pelajar dan atau pekerja. Setelah mengetahui sebaran karakteristik penumpang domestik angkutan laut di pelabuhan Sri Bintan Pura, penyedia jasa pelayanan dalam memberikan pelayanannya harus sesuai apa yang dibutuhkan dari pengguna jasa tersebut dan sesuai dengan karakteristik pengguna jasa yang dimaksud disini adalah penyelenggara pelabuhan.

1. Tingkat Kepuasan penumpang domestik terhadap pelayanan di pelabuhan Sri Bintan Pura Tanjungpinang.

Untuk mengetahui tingkat kepuasaan penumpang domestik terhadap pelayanan yang ada di pelabuhan Sri Bintan Pura Tanjungpinang, dalam penelitian ini menggunakan teknis analisis data Customer Satisfaction Index dan Importance Performance Analysis digunakan untuk mengetahui atribut - atribut pelayanan yang menurut pengguna jasa memberikan pengaruh yang besar terhadap tingkat kepuasan pengguna jasa serta atribut - atribut pelayanan yang menurut pengguna jasa perlu ditingkatkan kinerjanya. Untuk mendapatkan gambaran mengenai tanggapan atau persepsi penumpang domestik di pelabuhan Sri Bintan Pura Tanjungpinang yang telah menjadi responden, didasarkan pada dimensi kualitas pelayanan yang mengacu pada standar pelayanan penumpang angkutan laut menurut Peraturan Menteri Perhubungan No 119 Tahun 2015. Peraturan Menteri tersebut mengatur tentang standar pelayanan penumpang angkutan laut, peraturan tersebut mengatu hal - hal sebagai berikut: pelayanan keselamatan, pelayanan keamanan dan ketertiban, pelayanan kehandalan atau keteraturan, pelayanan kenyamanan, pelayanan kemudahan, dan pelayanan kesetaraan.

a. Customer Satisfaction Index (CSI)

Penelitian ini dimaksudkan untuk mengetahui tingkat kepuasan penumpang domestik pelabuhan Sri Bintan Pura Tanjungpinang . Tingkat kepuasaan tersebut diukur dengan angket/kuisioner dengan tingkat kinerja dan tingkat kepentingan yang berjumlah 31 butir pernyataan. Tingkat kepuasan penumpang domestik pelabuhan Sri Bintan Pura Tanjungpinang didasarkan pada dimensi kualitas pelayanan yang mengacu pada standar pelayanan penumpang angkutan laut menurut Peraturan Menteri Perhubungan No 119 Tahun 2015.

Peraturan Menteri tersebut mengatur tentang Pelayanan keselamatan, pelayanan keamanan dan ketertiban, pelayanan kehandalan atau keteraturan, pelayanan kenyamanan, pelayanan kemudahan, dan pelayanan kesetaraan. Deskripsi hasil penelitian masing - masing faktor pelayanan tersebut diuraikan sebagai berikut :

1) Pelayanan Keselamatan

Sesuai dengan Peraturan Menteri Perhubungan Nomor 119 Tahun 2015 tentang perubahan atas peraturan Menteri Perhubungan Nomor 37 Tahun 2015 tentang Standar Pelayanan Penumpang Angkutan Laut, maka pelayanan yang termasuk dalam keselamatan di pelabuhan sebagai berikut :

a) Pemberian informasi menyangkut system keselamatan yang ada dan fasilitas keselamatan yang tersedia,

b) Pemberian informasi menyangkut system kesehatan yang ada dan fasilitas kesehatan yang tersedia.

Persepsi yang diberikan responden dalam penelitian ini tentang pelayanan keselamatan penumpang domestik di pelabuhan Sri Bintan Pura Tanjungpinang , dimana tingkat kepuasaanya sesuai nilai Customer Satisfaction Index sebesar $74,510 \%$, yang mana angka tersebut berada pada tabel kriteria Customer Satisfaction Index terdapat pada range angka index $71 \%<\mathrm{X} \leq 77 \%$ yang memepunyai kriteria Cause Forconcern atau masih mengkhawatirkan.

2) Pelayanan Keamanan dan Ketertiban

Standar Pelayanan penumpang angkutan laut menyangkut pemberian pelayanan tentang keamanan dan ketertiban, yang meliputi :

a) Naik turun penumpang dari dan ke kapal

b) Fasilitas keamanan berupa ruang tunggu penumpang dan pengantar

c) Pos dan petugas keamanan

d) Informasi gangguan keamanan

e) Peralatan dan pendukung keamanan

Persepsi yang diberikan responden dalam penelitian ini tentang pelayanan keamanan dan ketertiban penumpang domestik di pelabuhan Sri Bintan Pura Tanjungpinang, dimana tingkat kepuasaanya sesuai nilai Customer Satisfaction Index sebesar $69,807 \%$, yang mana angka tersebut berada pada tabel kriteria Customer Satisfaction Index terdapat pada range angka index $64 \%<\mathrm{X}$ $\leq 71 \%$ yang memepunyai kriteria poor atau buruk.

3) Pelayanan Kehandalan atau Keteraturan

Standar Pelayanan penumpang angkutan laut menyangkut pemberian pelayanan yang handal dan teratur, diharapkan mampu memberikan pelayanan yang baik menyangkut hal - hal sebagai berikut :

a) Kemudahan untuk mendapatkan tiket 
b) Informasi jadwal kedatangan dan keberangkatan kapal

Persepsi yang diberikan responden dalam penelitian ini tentang pelayanan kehandalan atau ketaraturan penumpang domestik di pelabuhan Sri Bintan Pura Tanjungpinang, dimana tingkat kepuasaanya sesuai nilai Customer Satisfaction Index sebesar $81,799 \%$, yang mana angka tersebut berada pada tabel kriteria Customer Satisfaction Index terdapat pada range angka index $80 \%<\mathrm{X}$ $\leq 84 \%$ yang memepunyai kriteria Good atau Baik.

4) Pelayanan Kenyamanan

Standar pelayanan penumpang angkutan laut menyangkut pemberian pelayanan keanyamanan di pelabuhan, hal ini bertujuan agar memberikan pelayanan yang baik terutama dalam memberikan kenyamanan kepada penumpang kapal laut, yang meliputi :

a) Kenyamanan dan kelengkapan fasilitas ruang tunggu;

b) Prosedur pemeriksaan pada gate/koridor maupun boarding;

c) Ketersediaan, kenyamanan dan kebersihan toilet;

d) Ketersediaan dan kemudahan mendapatkan tempat ibadah;

e) Ketersediaan dan kecukupan lampu penerangan;

f) Ketersediaan dan kecukupan fasilitas kebersihan;

g) Ketersediaan dan kecukupan fasilitas pengatur suhu;

h) Ketersediaan dan keterjangkauan ruang pelayanan kesehatan;

i) Ketersediaan tempat khusus merokok;

Persepsi yang diberikan responden dalam penelitian ini tentang pelayanan kenyamanan penumpang domestik di pelabuhan Sri Bintan Pura Tanjungpinang , dimana tingkat kepuasaanya sesuai nilai Customer Satisfaction Index sebesar $72,123 \%$, yang mana angka tersebut berada pada tabel kriteria Customer Satisfaction Index terdapat pada range angka index $71 \%<\mathrm{X} \leq 77 \%$ yang memepunyai kriteria Cause Forconcern atau masih mengkhawatirkan.

5) Pelayanan Kemudahan

Standar pelayanan penumpang angkutan laut menyangkut pemberian pelayanan kemudahan di pelabuhan, hal ini bertujuan agar memberikan pelayanan yang baik terutama dalam memberikan kemudahan kepada penumpang kapal laut, yang meliputi :

a) Informasi pelayanan

b) Waktu kedatangan dan keberangkatan kapal

c) Informasi gangguan perjalanan

d) Informasi angkutan lanjutan

e) Fasilitas layanan penumpang f) Fasilitas kemudahan naik/turun penumpang

g) Tempat parkir

h) Fasilitas layanan bagasi penumpang.

Persepsi yang diberikan responden dalam penelitian ini tentang pelayanan kemudahan penumpang domestik di pelabuhan Sri Bintan Pura Tanjungpinang, dimana tingkat kepuasaanya sesuai nilai Customer Satisfaction Index sebesar $71,424 \%$, yang mana angka tersebut berada pada tabel kriteria Customer Satisfaction Index terdapat pada range angka index $71 \%<\mathrm{X} \leq 77 \%$ yang memepunyai kriteria Cause Forconcern atau masih mengkhawatirkan.

6) Pelayanan Kesetaraan di Pelabuhan

Standar pelayanan penumpang angkutan laut menyangkut pemberian pelayanan kesetaraan di pelabuhan, hal ini bertujuan agar memberikan pelayanan yang baik terutama dalam memberikan prioritas pelayanan kepada penumpang kapal laut yang memiliki kebutuhan khusus, yang meliputi :

a) Fasilitas bagi penyandang disfabel

b) Fasilitas bagi ibu menyusui

Persepsi yang diberikan responden dalam penelitian ini tentang pelayanan kesetaraan penumpang domestik di pelabuhan Sri Bintan Pura Tanjungpinang , dimana tingkat kepuasaanya sesuai nilai Customer Satisfaction Index sebesar $71,386 \%$, yang mana angka tersebut berada pada tabel kriteria Customer Satisfaction Index terdapat pada range angka index $71 \%<\mathrm{X} \leq 77 \%$ yang memepunyai kriteria Cause Forconcern atau masih megkhawatirkan.

2. Importance Perfomance Analysis (IPA)

Untuk mengetahui atribut - atribut pelayanan yang menurut pengguna jasa memberikan pengaruh yang besar terhadap tingkat kepuasan pengguna jasa serta atribut - atribut pelayanan yang menurut pengguna jasa perlu ditingkatkan kinerjanya, dengan menggunakan diagram kartesius Importance Perfomance Analysis.

Dari hasil perhitungan diperoleh tingkat kesesuaian total antara tingkat kinerja dan tingkat kepentingan yaitu 98,04\% dimana hasil tersebut masih dibawah $100 \%$. Sehingga dapat dikatakan tingkat kepuasan penumpang domestik secara total belum maksimal, karena tingkat kinerja penyelenggara pelabuhan belum sesuai dengan kepentingan penumpang domestik di pelabuhan Sri Bintan Pura Tanjungpinang.

Untuk mengetahui atribut - atribut pelayanan yang menurut pengguna jasa memberikan pengaruh besar terhadap tingkat kepuasan pengguna jasa serta atribut - atribut pelayanan yang menurut pengguna jasa perlu ditingkatkan kinerjanya dengan memetakan atribut - atribut pelayanan tersebut yang dibagi dalam empat kolom yang di batasi oleh dua garis yang saling tegak 
lurus pada $\left(\mathrm{X}^{\overline{ }}, \mathrm{Y} \overline{\overline{ }}\right)$. Dimana sumbu $\mathrm{X}^{=}$merupakan rata - rata dari skor rata - rata tingkat kinerja dan sumbu $\mathrm{Y}^{=}$merupakan rata - rata dari rata - rata skor tingkat kepentingan.

Dari hasil analisa perhitungan yang telah dilakukan di atas dapat di jabarkan ke dalam diagram kartesius dengan bantuan aplikasi SPSS dan Ms. Excel. Empat bagian dalam diagram kartesius ini dibagi oleh dua buah garis yang berpotongan tegak lurrus yaitu pada titik $\mathrm{X}^{=}=3,61$ dan titik $\mathrm{Y}^{=}=3,68$, seperti tampak pada gambar berikut ini.

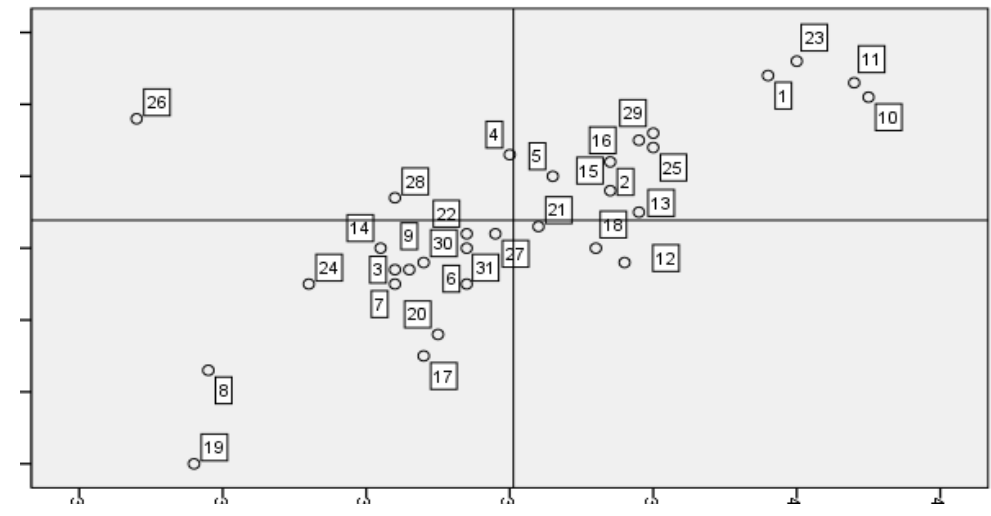

Gambar 1. Diagram Cartesius

Adapun penjelasan dari diagram kartesius di atas adalah :

a) Pada kuadran A terdapat nomor pernyataan 4,

26 , dan 28 , dimana penyataan - penyataan tesebut yaitu:

(1) Pernyataan no. 4 Keamanan dan ketertiban ruang tunggu dan terminal di pelabuhan.

(2) Pernyataan no. 26 Ketersediaan fasilitas parkir kendaraan di pelabuhan.

(3) Pernyataan no. 28 Ketersediaan fasilitas bagi penyandang disfable di pelabuhan.

Pada kuadran ini menunjukan bahwa atribut atribut tersebut perlu penanganan yang diprioritaskan karena keberadaan atribut - atribut ini yang dinilai sangat penting oleh penumpang, akan tetapi pelaksanaan pelayanan oleh penyelenggara pelabuhan belum sesuai dengan keinginan para penumpang, yang menimbulkan kekecewaan atau rasa tidak puas pada penumpang. b) Pada kuadran B terdapat nomor pernyataan 1,2, $5,10,11,13,15,16,23,25$, dan 29, dimana pernyataan - pernyataan tersebut adalah :

(1) Pernyataan no. 1 Fasilitas keselamatan di pelabuhan memadai.

(2) Pernyataan no. 2 Ketersediaan peralatan untuk kondisi darurat seperti alat pemadam kebakaran, petunjuk jalur evakuasi, titik kumpul evakuasi dan nomor telepon darurat.

(3) Pernyataan no. 5 Keamanan dan ketertiban ruang pengantar/penjemput di pelabuhan.
(4) Pernyataan no. 10 Kemudahan dan ketertiban ruang pengantar/penjemput di pelabuhan.

(5) Pernyataan no. 11 Ketersediaan informasi jadwal kedatangan dan keberangkatan kapal.

(6) Pernyataan no. 13 Ketersediaan gate koridor boarding di terminal penumpang.

(7) Pernyataan no. 15 Ketersediaan tempat ibadah di terminal penumpang.

(8) Pernyataan no. 16 Ketersediaan lampu penerangan di ruang tunggu, terminal penumpang dan pelabuhan.

(9) Pernyataan no. 23 Ketersediaan papan informasi atau petunjuk arah untuk fasilitas yang ada di pelabuhan (lokasi loket penjualan tiket, terminal penumpang, musolah, toilet/WC, dan lain-lain).

(10) Pernyataan no. 25 Ketersediaan fasilitas kemudahan untuk naik/turun penumpang di pelabuhan.

(11) Pernyataan no. 29 Kualitas fasilitas bagi penyandang disfable di pelabuhan.

Pada kuadran ini menunjukan bahwa atribut atribut diatas perlu di pertahankan karena pada umumnya tingkat pelaksanaan/kinerja pelayanan telah sesuai dengan kepentingan penumpang, sehingga dapat memuaskan penumpang.

c) Pada kuadran C terdapat nomor pernyataan 3, 6, $7,8,9,14,17,19,20,22,24,27,30$ dan 31 , dimana pernyataan - pernyataan tersebut adalah:

(1) Pernyataan no. 3 Ketersediaan infomasi dan fasilitas kesehatan seperti ruang kesehatan,P3K, Kursi roda, tandu, dan petugas kesehatan.

(2) Pernyataan no. 6 Keamanan dan ketertiban pada saat naik turun penumpang dari dan ke kapal.

(3) Pernyataan no. 7 Fasilitas pos keamanan dan pelayanan petugas pos di pelabuhan.

(4) Pernyataan no. 8 Ketersediaan informasi untuk pengaduan gangguan keamanan di pelabuhan.

(5) Pernyataan no 9. Ketersediaan peralatan dan pendukung keamanan (CCTV, metal detector, mobil patroli, dll).

(6) Pernyataan no. 14 Ketersediaan toilet di terminal penumpang.

(7) Pernyataan no. 17 Ketersediaan fasilitas kebersihan di terminal penumpang dan pelabuhan.

(8) Pernyataan no. 19 Ketersediaan ruang pelayanan kesehatan di terminal penumpang.

(9) Pernyataan no. 20 Ketersediaan fasilitas area merokok di terminal penumpang. 
(10) Pernyataan no. 22 Ketersediaan informasi gangguan perjalanan kapal.

(11) Pernyataan no. 24 Ketersediaan informasi mengenai angkutan lanjutan yang ada di pelabuhan, baik mengenai jenis angkutan, jadwal, rute, tarif dan penunjuk arah angkutan lanjutan.

(12) Pernyataan no. 27 Pelayanan bagasi penumpang, seperti ketersediaan trolley, porter berseragam dan alat timbangan.

(13) Pernyataan no. 30 Ketersediaan ruang ibu menyusui di pelabuhan.

(14) Pernyataan no. 31 Kualitas fasilitas bagi ibu menyusui di pelabuhan.

Pada kuadran ini menunjukan bahwa atribut atribut tersebut dinilai masih dianggap kurang penting bagi pelanggan, sedangkan pelaksanaan/kinerja pelayanannya biasa saja atau cukup baik.

d) Pada kuadran D terdapat nomor pernyataan 12, 18 dan 21 , dimana pernyataan - pernyataan tersebut adalah :

(1) Pernyataan no. 12 Kapsitas ruang tunggu dan terminal di pelabuhan yang memadai.

(2) Pernyataan no. 18 Ketersediaan fasilitas pengatur suhu/pendingin di terminal penumpang.

(3) Pernyataan no. 21 Ketersediaan informasi pelayanan penumpang di pelabuhan.

Pada kuadran ini menunjukan bahwa atribut atribut tersebut dinilai berlebihan dalam pelaksanaan/kinerja pelayanannya, hal ini di sebabkan karena pelanggan menganggap tidak terlalu penting terhadap adanya atribut - atribut tersebut, akan tetapi dalam pelaksanaanya dilakukan dengan baik sehingga dirasa berlebihan.

Berdasarkan analisis data di atas, diperoleh hasil bahwa penumpang domestik cukup puas namun belum maksimal dilihat dari hasil analisis Customer Satisfaction Index tiap indikator standar pelayanan penumpang kapal laut. Hal ini disebabkan adanya ketidaksesuaian antara tingkat kepentingan atau harapan penumpang terhadap kinerja dari penyelenggara pelabuhan Sri Bintan Pura Tanjungpinang yang dapat di lihat pada tabel 4.21 Hasil perhitungan tingkat kesesuaian, dimana tingkat kinerja penyelenggara pelabuhan masih dibawah dari tingkat kepentingan penumpang domestik di pelabuhan Sri Bintan Pura Tanjungpinang. Maka dari itu perlu adanya :

1. Perhatian khusus serta peningkatan terhadap pelayanan yang belum dapat memuaskan para penumpang domestik pelabuhan Sri Bintan Pura Tanjungpinang. Pelayanan yang harus di prioritaskan seperti :

a. Pelayanan keamanan dan ketertiban pada ruang tunggu dan terminal di pelabuhan. b. Pelayanan kemudahan pada ketersediaan fasilitas parkir kendaraan di pelabuhan.

c. Pelayanan kesetaraan pada ketersediaan fasilitas bagi penyandang disfabel.

2. Mempertahankan pelayanan yang telah memuaskan penumpang domestik pelabuhan Sri Bintan Pura Tanjungpinang. Pelayanan tersebut ialah :

a. Pelayanan keselamatan pada fasilitas keselamatan dan ketersediaan peralatan untuk kondisi darurat seperti alat pemadam kebakaran, petunjuk jalur evakuasi, titik kumpul evakuasi dan nomor telepon darurat.

b. Pelayanan keamanan dan ketertiban pada keamanan dan ketertiban ruang pengantar atau penjemput di pelabuhan.

c. Pelayanan kehandalan dan keteraturan pada kemudahan mendapatkan tiket sesuai tujuan perjalanan yang diinginkan dan ketersediaan informasi jadwal kedatangan dan keberangkatan kapal.

d. Pelayanan kenyamanan pada ketersediaan gate kooridor boarding, tempat ibadah, dan lampu penerang di pelabuhan.

e. Pelayanan kemudahan pada ketersediaan papan informasi atau petunjuk arah untuk fasilitas seperti (lokasi loket penjualan tiket, terminal penumpang, musolah, toilet/WC,dll) dan fasilitas kemudahan untuk naik dan atau turun penumpang di pelabuhan.

f. Pelayanan kesetaraan pada kualitas fasilitas bagi peyandang disfabel di pelabuhan.

3. Peninjauan atau pemantauan secara rutin dan berkelanjutan yang dilakukan oleh penyelenggara pelabuhan terhadap sarana dan prasana yang ada di pelabuhan Sri Bintan Pura Tanjungpinang guna menunjang kualitas pelayanan yang diberikan, sehingga dapat memberikan pelayanan yang optimal yang mampu memberikan kepuasan kepada pengguna jasa (penumpang domestik) secara maksimal.

Berdasarkan alternatif pemecahan masalah diatas, setiap alternatif juga perlu dievaluasi dalam kaitannya dengan seberapa baik alternatif itu akan mencapai suatu hasil pemecahan masalah. Adapun evaluasi terhadap alternatif - alternatif tersebut adalah :

1. Perhatian khusus serta peningkatan terhadap pelayanan yang belum dapat memuaskan para penumpang domestik pelabuhan Sri Bintan Pura Tanjungpinang. Pelayanan yang harus di prioritaskan seperti :

a. Pelayanan keamanan dan ketertiban pada ruang tunggu dan terminal di pelabuhan. 
b. Pelayanan kemudahan pada ketersediaan fasilitas parkir kendaraan di pelabuhan.

c. Pelayanan kesetaraan pada ketersediaan fasilitas bagi penyandang disfabel.

Alternatif ini tidaklah mudah dan murah. Namun, dengan dilakukannya peningkatan terhadap pelayanan diatas akan memberikan kepuasan kepada pengguna jasa (penumpang), dan mereka akan merasa puas terhadap pelayanan yang diberikan oleh penyelenggara pelabuhan Sri Bintan Pura Tanjungpinang.

2. Mempertahankan pelayanan yang telah memuaskan penumpang domestik pelabuhan Sri Bintan Pura Tanjungpinang. Pelayanan tersebut ialah :

a. Pelayanan keselamatan pada fasilitas keseleamatan dan ketersediaan peralatan untuk kondisi darurat seperti alat pemadam kebakaran, petunjuk jalur evakuasi, titik kumpul evakuasi dan nomor telepon darurat.

b. Pelayanan keamanan dan ketertiban pada keamanan dan ketertiban ruang pengantar atau penjemput di pelabuhan.

c. Pelayanan kehandalan dan keteraturan pada kemudahan mendapatkan tiket sesuai tujuan perjalanan yang diinginkan dan ketersediaan informasi jadwal kedatangan dan keberangkatan kapal.

d. Pelayanan kenyamanan pada ketersediaan gate kooridor boarding, tempat ibadah, dan lampu penerang di pelabuhan.

e. Pelayanan kemudahan pada ketersediaan papan informasi atau petunjuk arah untuk fasilitas seperti (lokasi loket penjualan tiket, terminal penumpang, musolah, toilet/WC,dll) dan fasilitas kemudahan untuk naik dan atau turun penumpang di pelabuhan.

f. Pelayanan kesetaraan pada kualitas fasilitas bagi peyandang disfabel di pelabuhan.

Alternatif ini tidak mudah dikarenakan perlu adanya konsistensi pada penyelenggara pelabuhan dalam memberikan pelayanan kepada pengguna jasa (penumpang) yang menggunakan jasa angkutan laut di pelabuhan Sri Bintan Pura Tanjungpinang.

3. Peninjauan atau pemantauan secara rutin dan berkelanjutan yang dilakukan oleh penyelenggara pelabuhan terhadap sarana dan prasana yang ada di pelabuhan Sri Bintan Pura Tanjungpinang guna menunjang kualitas pelayanan yang diberikan, sehingga dapat memberikan pelayanan yang optimal yang mampu memberikan kepuasan dari pengguna jasa (penumpang domestik) secara maksimal.
Alternatif pemecahan masalah ini terbilang mudah, karena penyelenggara pelabuhan dapat melakukannya secara rutin dengan melihat dan meninjau langsung datang ke pelabuhan dan atau dengan melakukan sidak mendadak ke pelabuhan untuk melihat sarana dan prasaran apa saja yang masih belum memadai untuk dapat memberikan pelayanan yang optimal kepada penumpang yang akan memberikan kepuasan dari pengguna jasa (penumpang domestik) pelabuhan Sri Bintan Pura Tanjungpinang.

\section{KESIMPULAN}

Berdasarkan hasil analisis data yang dilakukan, maka kesimpulan yang dapat diambil dalam penelitian ini adalah tingkat kepuasan pelanggan berdasarkan Customer Satisfaction Index atas pelayanan yang ada di pelabuhan Sri Bintan Pura Tanjungpinang, diperoleh penumpang domestik di pelabuhan Sri Bintan Pura cukup puas namun belum maksimal atas pelayanan yang di berikan oleh penyelenggara pelabuhan Sri Bintan Pura Tanjungpinang. Hal ini dapat dilihat dari perhitungan hasil diatas rata-rata masih mengkhawatirkan.

Berdasarkan kesimpulan penelitian di atas, saran yang dapat disampaikan bagi pengelola pelabuhan Sri Bintan Pura Tanjungpinang, yaitu :

1. Perlunya peningkatan dan peninjauan pada pelayanan yang belum dapat memberikan kepuasan bagi penumpang domestik pelabuhan Sri Bintan Pura Tanjungpinang secara maksimal. Dalam hal ini pelayanan yang masih dalam kategori Cause Forconcren atau masih mengkhawatir dan poor atau

2. Mempertahankan secara konsisten pada pelayanan yang telah memberikan kepausan bagi penumpang domestik pelabuhan Sri Bintan Pura Tanjungpinang,

3. Melakukan peninjauan secara rutin dan berkala terhadap kualitas pelayanan yang di rasakan langsung oleh penumpang domestik untuk dapat mengetahui hal - hal yang diinginkan dan dibutuhkan oleh penumpang domestik sehingga dapat memberikan kepuasan kepada penumpang domestik di pelabuhan Sri Bintan Pura secara maksimal.

\section{DAFTAR PUSTAKA}

[1] Arikunto. 2010. Manajemen Penelitian, Jakarta : PT Rineka Cipta

[2] Aritonang, Lerbin R. 2005. Kepuasan Pelanggan. Jakarta : PT Gramedia Pustaka Utama

[3] Tjiptono, Fandy. 2011. Service Management. Yogyakarta : PT Andi Offset 
[4] Kotler, Philip dan Kevin L. Keller. 2008. Manajemen Pemasaran. Jakarta : PT Indeks

[5] Marzolina, dan S. R. (2010). Analisis Kepuasan Pelanggan (Penumpang Domestik) Terhadap Kualitas Pelayanan Pada Pt. Angkasa Pura H (Persero) Cabang Bandara Sultan Syarif Kasim H Pekanbaru. Jurnal Ekonomi, 18.

[6] Moenir. 2010. Manajemen Pelayanan Umum Di Indonesia. Jakarta : PT Bumi Aksara

[7] Novel1, H., \& , Humala L. Napitupulu, D. (2013). Penilaian Tingkat Kepuasan Pasien Terhadap Pelayanan Jasa Puskesmas Medan Johor Dengan Metode Servperf (Service Performance) Dan Customer Satisfaction Index. E-Jurnal Teknik Industri FT USU

[8] Peraturan Menteri Perhubungan No. 119 Tahun 2015 tentang Standard Pelayanan Penumpang Angkutan Laut.

[9] Sugiyono, P. D. (2013). METODE PENELITIAN BISNIS (Pendekatan Kuantitatif, Kualitatif, dan R\&D). Bandung: Alfabeta.

[10] Supranto, J. 2006. Pengukuran Tingkat Kepuasan Pelanggan untuk Menaikan Pangsa Pasar. Jakarta : PT Rineka Cipta

[11] Tjiptono, Fandy dan Gregious Chandra. 2011. Service, Quality dan Satisfaction. Yogyakarta : PT Andi Offset

[12] Undang - undang RI No. 17 Tahun 2008 tentang Pelayaran. Bandung

[13] Wijaya, Tonny. 2018. Manajemen Kualitas Jasa. Jakarta : PT Indeks 